\title{
CORPORATE CULTURE IN INTEGRATED REPORTING
}

\author{
DOI: 10.17261/Pressacademia.2019.1055 \\ PAP- V.9-2019(2)-p.6-8
}

\section{Arzu Ozsozgun Caliskan ${ }^{1}$, Emel Esen ${ }^{2}$}

${ }^{1}$ Yildiz Technical University, Davutpasa Campus 3422 Esenler, Istanbul, Turkey. ozsozgun@yildiz.edu.tr, ORCID: 0000-0001-6209-4952

${ }^{2}$ Yildiz Technical University, Davutpasa Campus 3422 Esenler, Istanbul, Turkey. emeloz@yildiz.edu.tr, ORCID: 0000-0001-5753-3252

\section{To cite this document}

Caliskan, A.O., Esen, E., (2019). Corporate culture in integrated reporting, PressAcademia Procedia (PAP), V.9, p.6-8

Permemant link to this document: http://doi.org/10.17261/Pressacademia.2019.1055

Copyright: Published by PressAcademia and limited licenced re-use rights only.

\section{ABSTRACT}

Purpose- Corporate culture represents shared values, assumptions, norms, beliefs and strategies of the organization. Both national and corporate culture can effect the level of corporate transparency regarding strategic, economic, social, environmental and governance performance. The main purpose of this study is to understand the role of cultural system in integrated reporting.

Methodology- There is a lack of research on managerial attitudes and culture on integrated reporting. In this study, we make theoretical suggestions for further studies to understand cultural dimensions and its role in integrated reporting.

Findings- Findings show that stakeholders' expectations in different cultural system can shape the presented information in integrated reports how the organization operates and how it creates and maintains value. Therefore, it is suggested that integrated reports can determined by a corporate cultural system. Also, higher corporate responsibility as an important aspect of a culture can effect the publishing integrated reports.

Conclusion- Companies should adapt the differences in corporate rules, structures, all cultural mechanisms to the practice of integrated reporting. Furthermore, they should be more concerned with internal process and improving their culture while focusing on reporting.

Keywords: Corporate culture, national culture, stakeholders, integrated report.

JEL Codes: M1, M10, M14

\section{INTRODUCTION}

Corporate reporting provides information that will assist internal and external users in decision making. And traditionally, it is accepted that the main objective of corporate reports is to communicate financial and non-financial measurements of and information about the resources and performance of a company (ASSC, 1975). Listed companies have to disclose periodic and occasional information reports to financial markets. Especially, because of the last corporate scandals that have been taken place in the last decade force companies to disclose information not only their financial performance but also other aspects of their activity. And countries' legal systems influence the listed companies' disclosure practices (Hernández-Madrigal et al., 2012). On the other hand, only mandatory disclosure result from legistlation and regulation. Corporate disclosure involves both compulsory and voluntary basis information.

Culture and corporate transparency is related to each other (García-Sánchez et al., 2013). And corporate reports as a mean of corporate transparency is affected by the company's culture. According to Molenaar et al. (2002), culture consists of the beliefs, values and behaviors that are consistent among all members of the corporation. As it is stated above, listed companies disclose financial information on a regular basis, and some companies disclose non-financial information to their stakeholders. There are various non-financial reports, such as sustainability, social responsibility and ethical reports that enable companies to become more accountable to a range of stakeholders (Johansen, 2010). In today's complex business world, it is vital to idenfy and understand what drivers affecting business value creation. And financial reports are not enough to present the value creation process (Chandler and Teckchandani, 2015).

Integrating reporting $(<\mid R>)$ as a new reporting initiative aims to reduce the imperfections of current corporate reporting (Zhou et al., 2017). Adoption of integrated reporting is not compulsory most of the countries and the culture of organizations would be an important driver for voluntarily adopting integrated reporting. The main purpose of this study is to understand the role of cultural system in integrated reporting.

For this perspective, we first discuss the organizational culture and integrated reporting, then we make some suggestions for further studies. 


\section{LITERATURE REVIEW}

Culture is an interdisciplinary concept which incorporates psychology, sociology, anthropology and social psychology (Lewis, 1998). The basic value of citizens and corporations are affected by national culture (García-Sánchez et al., 2013). And a country's culture determines the limits of corporate responsbility mindset (Jensen and Berg, 2012).

It is possible to define organizational culture in various ways. The simplest definition of organizational culture would be as the the environment in which we work; these are the member's behaviors, attitudes, beliefs, skills, perspectives, habits and prejudices (Madu, 2012). Understanding the organizational culture is necessary to understand the organization sind it reflects the standards, values and assumptions upon which decisions are made and actions taken by a firm's members and managers (Liao, 2018). Shared values shows what is important in the organization and the imputed importance effect the organization's structures and control systems to produce behavioral norms (the way we do things around here) (Henri, 2006).

Employees' daily working behaviours and communications styles within the organizations are formed by organizational culture and the culture also reflects how the company hierarchy is built. Just like every individual is different, every organization is different (Tseng, 2010). Fort that reason, understanding an organization's culture could help to discover the reasons behind its practices and limits of its transparency. In today's challenging business world, companies find themselves to respond to stakeholders need to be informed. The traditional reporting model was developed for a industrial world (IIRC, 2011) and mostly focused on interest of shareholders. On the other hand, a growing number of stakeholders are concerned about the impact of companies on environment and society. In other words, companies need to win the acceptance of society in order to survive and thrive (Adams and Frost, 2008).

Corporate reports are the main communication mean between the company and its stakeholders for that purpose. There are different reporting reporting frameworks that included companies' non-financial effects. But also, stakeholders, especially investors demand economic, social and environmental information in an integrated manner for decision making. Integrated reporting is the reporting framework that promise to present the value creation of an organizatioan by combining all economic, social an environmental information in the report. Integrated reporting proposed by The International Integrated Reporting Council (IIRC) which is a global coalition of regulators, investors, companies, standard setters, the accounting profession and NGOs (IIRC, 2019).

An integrated report contains important information for decision making since it presents an organisation's strategy, governance performance and prospects in a way that reflects the commercial, social and environmental context within which it operates (IIRC, 2019). Adoption of integrated reporting is not compulsory in most of the countries (Cheng et al., 2014). According to literature, certain specific charactarestics of companies, such as size, industry, profitability, etc. have role in publication of financial and sustainability reports. On the other hand, there is limited research that investigates the factors having role in publishing integrated report (Frias-Aceituno et al., 2013).

In regard to national culture, companies located in countries societies characterised by concern for the public good, place greater emphasis on sustainable issues, ethics and good governance publish integrated reports containing relevant, comparable information for decision making. Research results show that in similar cultural conditions produce homogeneous patterns of behaviour regarding integrated reporting (García-Sánchez et al., 2013). On the other hand, companies that have more transparent financial disclosure policies could also have better nonfinancial disclosure (Dhaliwal et al., 2012). In addition, integrated reporting could offer opportunities to the culture of an organisation towards more sustainable outcomes (De Villiers et al., 2014). So the role of corporate culture in integrated reporting could be worth to examine. In addition, further studies are needed to analyse the impact made by corporate cultural values on the reporting practices of companies elaboration of integrated information (García-Sánchez et al., 2013).

\section{DATA AND METHODOLOGY}

There is a lack of research on managerial attitudes and culture on integrated reporting. In this study, we make theoretical suggestions for further studies to understand cultural dimensions and its role in integrated reporting.

\section{FINDINGS}

Findings show that stakeholders' expectations in different cultural system can shape the presented information in integrated reports how the organization operates and how it creates and maintains value. Therefore, it is suggested that integrated reports can determined by a corporate cultural system. Also, higher corporate responsibility as an important aspect of a culture can effect the publishing integrated reports.

\section{CONCLUSION}

Responding stakeholders' expectations is important for companies to survive. Corporate reports are a means to reach information and decision making. In line witt the changes in information demands of users of corporate reporting over time, new reporting frameworks are presented. Integrated reporting is an alternative that promises to reduce considerably the lacks presented in the previous reporting model, namely financial reporting and nonfinancial reporting. Integrated reporting is voluntary in most countries and the number of reporting companies is growing. Both the national culture and corporate culture have impact on the reporting practices of corporations. To satisfy its stakeholders' demands and present itself more fairly, companies should adapt the differences in corporate rules, structures, all cultural mechanisms to the practice of integrated reporting. Furthermore, they should be more concerned with internal process and improving their culture while focusing on reporting. 


\section{REFERENCES}

Adams, C. A., \& Frost, G. R. (2008). Integrating sustainability reporting into management practices. In: Accounting Forum. Elsevier, 32(4), 288-302.

ASSC (1975), "The Corporate Report," Discussion Paper-Accounting Standards Steering Committee: London.

Chandler, J. D., \& Teckchandani, A. (2015). Using social constructivist pedagogy to implement liberal learning in business education. Decision Sciences Journal of Innovative Education, 13(3), 327-348.

Cheng, M., Green, W., Conradie, P., Konishi, N., \& Romi, A. (2014). The international integrated reporting framework: key issues and future research opportunities. Journal of International Financial Management \& Accounting, 25(1), 90-119.

De Villiers, C., Rinaldi, L., \& Unerman, J. (2014). Integrated Reporting: Insights, gaps and an agenda for future research. Accounting, Auditing \& Accountability Journal, 27(7), 1042-1067.

Dhaliwal, D. S., Radhakrishnan, S., Tsang, A., \& Yang, Y. G. (2012). Nonfinancial disclosure and analyst forecast accuracy: International evidence on corporate social responsibility disclosure. The Accounting Review, 87(3), 723-759.

Frias-Aceituno, J. V., Rodríguez-Ariza, L., \& García-Sánchez, I. M. (2013). Is integrated reporting determined by a country's legal system? An exploratory study. Journal of cleaner production, 44, 45-55.

García-Sánchez, I. M., Rodríguez-Ariza, L., \& Frías-Aceituno, J. V. (2013). The cultural system and integrated reporting. International business review, 22(5), 828-838.

Henri, J. F. (2006). Organizational culture and performance measurement systems. Accounting, organizations and society, 31(1), 77-103.

Hernández-Madrigal, M., Blanco-Dopico, M. I., \& Aibar-Guzmán, B. (2012). The influence of mandatory requirements on risk disclosure practices in Spain. International Journal of Disclosure and Governance, 9(1), 78-99.

Jensen, J. C., \& Berg, N. (2012). Determinants of traditional sustainability reporting versus integrated reporting. An institutionalist approach. Business Strategy and the Environment, 21(5), 299-316.

Johansen, T. R. (2010). Employees, non-financial reports and institutional arrangements: A study of accounts in the workplace. European Accounting Review, 19(1), 97-130.

Lewis, D. (1998). How useful a concept is organizational culture?. Strategic Change, 7(5), 251-260.

Liao, Z. (2018). Corporate culture, environmental innovation and financial performance. Business Strategy and the Environment, 27(8), 13681375.

Madu, B. C. (2012). Organization culture as driver of competitive advantage. Journal of Academic and Business Ethics, $5,1$.

Molenaar, K., Brown, H., Caile, S., \& Smith, R. (2002). Corporate culture. Professional Safety, 47(7), 18-27.

The International Integrated Reporting Committee (IIRC). (2011). Towards integrated reporting. Communicating value in the 21st century. IIRC.www.theiirc.org

The International Integrated Reporting Council (IIRC) (2019). https://integratedreporting.org/. Accessed [27.6.2019].

Tseng, S. M. (2010). The correlation between organizational culture and knowledge conversion on corporate performance. Journal of knowledge management, 14(2), 269-284.

Zhou, S., Simnett, R., \& Green, W. (2017). Does integrated reporting matter to the capital market?. Abacus, 53(1), 94-132. 